\title{
BITES BY CORAL SNAKES (Micrurus spp.) IN CAMPINAS, STATE OF SÃO PAULO, SOUTHEASTERN BRAZIL
}

Fábio BUCARETCHI(1,5), Stephen HYSLOP(2,5), Ronan José VIEIRA(3,5), Adriana Safioli TOLEDO(5), Paulo Roberto MADUREIRA(4,5) \& Eduardo Mello DE CAPITANI(3,5)

\begin{abstract}
SUMMARY
Coral snakes (Micrurus spp.) are the main representatives of the Elapidae in South America. However, bites by these snakes are uncommon. We retrospectively reviewed the data from 11 individuals bitten by coral snakes over a 20-year period; four were confirmed (snake brought for identification) and seven were highly suspected (neuromuscular manifestations) cases of elapid envenoming. The cases were classified as dry-bite $(\mathrm{n}=1$, caused by M. lemniscatus; did not receive antivenom), mild $(\mathrm{n}=2$, local manifestations with no acute myasthenic syndrome; M. frontalis and Micrurus spp.), moderate $(\mathrm{n}=5$, mild myasthenia) or severe ( $\mathrm{n}=3$, important myasthenia; one of them caused by $M$. frontalis). The main clinical features upon admission were paresthesia (local, $n=9$; generalized, $n=2)$, local pain $(n=8)$, palpebral ptosis $(n=8)$, weakness $(n=4)$ and inability to stand up ( $n=3)$. No patient developed respiratory failure. Antivenom was used in ten cases, with mild early reactions occurring in three. An anticholinesterase drug was administered in the three severe cases, with a good response in two. No deaths were observed. Despite the high toxicity of coral snake venoms, the prognosis following envenoming is good. In serious bites by $M$. frontalis or M. lemniscatus, the venom of which acts postsynaptically, anticholinesterases may be useful as an ancillary measure if antivenom is unavailable, if there is a delay in obtaining a sufficient amount, or in those patients given the highest recommended doses of antivenom without improvement of the paralysis or with delayed recovery.
\end{abstract}

KEYWORDS: Antivenom; Anticholinesterase; Coral snakes; Envenomation; Micrurus spp.; Snakebites.

\section{INTRODUCTION}

In the Americas, the main representatives of the Elapidae family are the snakes of the genus Micrurus (coral snakes), of which 19 species with a wide distribution occur in Brazil ${ }^{20}$. Bites by these species are uncommon and are the fourth cause of bites by venomous snakes in Brazil $^{6}$. Coral snakes accounted for $0.65 \%(n=486)$ of the 75,312 bites by venomous snakes in Brazil for which the genus was officially notified from 2001 to 2004, with no record of any deaths (Secretaria de Vigilância em Saúde, Ministério da Saúde do Brasil, 2005, unpublished data). By comparison, a frequency of less than $2 \%$ (out of all snakebites) has been estimated for bites by Micrurus species in Central America ${ }^{5}$, and in the United States, bites by coral snakes (mainly Micrurus fulvius) account from $3.6 \%$ of those involving indigenous venomous snakes, based on records for the last 20 years (1983-2003) (911 coral snake bites in a total of 25,551 bites by venomous snakes) ${ }^{1}$.

Experimental studies have shown that Micrurus venoms are neurotoxic (their most important clinical effect) ${ }^{2,7,12,17,31,32}$, myotoxic ${ }^{14}$, hemorrhagic ${ }^{4,12}$ and edematogenic ${ }^{7}$, and some also are hemolytic ${ }^{7}$. The neurotoxins present in Micrurus venoms act either presynaptically (molecular mass of 12-60 $\mathrm{kDa}$, with phospholipase $\mathrm{A}_{2}$ activity, as in the case of $M$. corallinus) blocking the release of acetylcholine at the neuromuscular junction, or postsynaptically (molecular mass of 6-14 kDa, with no enzymatic activity, such as present in the venoms of $M$. frontalis, M. lemniscatus, $M$. nigrocinctus and other Micrurus species), by direct competition with acetylcholine for nicotinic cholinergic receptors in the postsynaptic membrane, in a manner similar to curare $\mathrm{e}^{2,7,12,17,31,32}$.

Whereas there have been detailed clinical reports and summaries of envenomations by coral snakes (Micrurus fulvius) in North America ${ }^{18,19,27}$, most studies of bites caused by Central and South American species have been published as case reports $8,23,26,28,30,32$, although an abstract of a relatively large series of bites $(\mathrm{n}=32)$ by $M$. corallinus and $M$. frontalis in southern Brazil has been published ${ }^{22}$. In this paper, we present a retrospective analysis of a series of patients bitten by coral snakes over a 20-year period, and examined at the University teaching hospital and the Poison Control Center, School of Medicine, State University of Campinas (UNICAMP), in Campinas, Southeastern Brazil.

(1) Departamento de Pediatria, Faculdade de Ciências Médicas, Universidade Estadual de Campinas (UNICAMP), Campinas, SP, Brasil.

(2) Departamento de Farmacologia, Faculdade de Ciências Médicas, Universidade Estadual de Campinas (UNICAMP), Campinas, SP, Brasil.

(3) Departamento de Clínica Médica, Faculdade de Ciências Médicas, Universidade Estadual de Campinas (UNICAMP), Campinas, SP, Brasil.

(4) Departamento de Medicina Preventiva e Social, Faculdade de Ciências Médicas, Universidade Estadual de Campinas (UNICAMP), Campinas, SP, Brasil

(5) Centro de Controle de Intoxicações, Faculdade de Ciências Médicas, Hospital das Clínicas, Universidade Estadual de Campinas (UNICAMP).

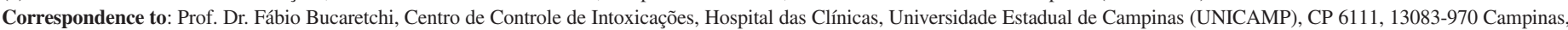
SP, Brazil. Phone: +55-19-3788-8875, Fax: +55-19-3788-8873. E-mail: bucaret@fcm.unicamp.br 


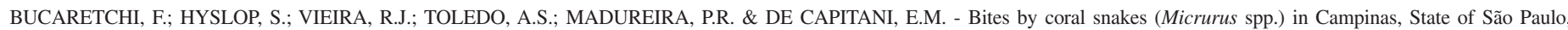
southeastern Brazil. Rev. Inst. Med. trop. S. Paulo, 48(3):141-145, 2006.

\section{PATIENTS AND METHODS}

The medical records of 22 patients reportedly bitten by coral snakes from May 1984 to December 2004 who were admitted to UNICAMP were individually reviewed by two of the authors (FB and EMDC), using an abstraction proforma in order to ensure consistency in the data selection. The variables recorded included time, day and month of the bite, identification of the offending snake, patient's age, sex and origin, bite site, time between the bite and admission to the hospital at UNICAMP, clinical manifestations, treatment given, including antivenom and therapeutic tests with anticholinesterase drugs, number of ampoules of antivenom, frequency and type of early reactions to antivenom, and general evolution of the case.

A total of 11 patients bitten by coral snakes fulfilled the inclusion criterion, namely, confirmed identification of the snake or a strong suspicion of being elapid bites based on the anamnesis (patient reported being bitten by a coral snake, but did not bring the snake), with clinical systemic manifestations indicative of acute myasthenic syndrome. All of the bites were arbitrarily classified as asymptomatic or dry-bites (with or without discrete local manifestations and which did not receive antivenom), mild (only local manifestations), moderate (evident signs of myasthenia, but no overt paralysis) and severe (signs of intense myasthenia with superficial respiration and inability to walk or remain in an erect position).

The antivenom used (10 mL/ampoule) was an enriched solution of $\mathrm{F}(\mathrm{ab})_{2}$ immunoglobulins obtained from horses immunized with a mixture of venom from two species, $M$. frontalis and M. corallinus. According to the manufacturer (Instituto Butantan, São Paulo, SP, Brazil), each $10 \mathrm{~mL}$ of antivenom neutralizes $15 \mathrm{mg}$ of reference venom of $M$. frontalis in mice.

The anticholinesterase drugs used were neostigmine methylsulfate (Prostigmine $^{\circledast}, 1 \mathrm{~mL}=0.5 \mathrm{mg}$ ) and edrophonium hydrochloride (Tensilon ${ }^{\circledast}, 1 \mathrm{~mL}=10 \mathrm{mg}$ ). The administration of anticholinesterase drugs was preceded by treatment with atropine sulfate $(1 \mathrm{~mL}=$ $0.25 \mathrm{mg}$ ).

\section{RESULTS}

Table 1 shows the main demographic characteristics of the patients. Most of the patients were attended within three $h$ of being bitten, with the most frequently bitten region being the distal segments of the fingers. A tourniquet was used in only one case.

Table 2 summarizes the principal clinical findings. The offending snake was identified in four cases ( $M$. frontalis, $\mathrm{n}=2$, one mild case and one severe case; M. lemniscatus, $\mathrm{n}=1$, a dry-bite; Micrurus sp., $\mathrm{n}$ $=1$, a mild case). The main local manifestations were pain and paresthesia. All moderate and severe cases showed neurological manifestations indicative of myasthenia, with palpebral ptosis being the most frequent. Fang marks were seen in three cases.

Among the patients classified as moderate, four showed neurotoxic manifestations within one hour after the bite and one after five hours. All of them showed progressive improvement after antivenom administration, with four being discharged $24 \mathrm{~h}$ post-admission, when
Table 1

Sex, age, interval between bite and admission to the university hospital at UNICAMP, and bite site in 11 patients bitten by coral snakes

\begin{tabular}{lc}
\hline Parameter & Findings \\
\hline Sex & \\
$\quad$ Male & 6 \\
$\quad$ Female & 5 \\
Age in years: median, (range), and & $27,(7-48)$, \\
mean age \pm 1 S.D. & $27 \pm 13$ \\
Interval between bite and admission to & 150 min, \\
hospital: median, (range) & $(45$ min -15 h) \\
$<3$ h & 7 \\
3 - 6 h & 2 \\
$>6$ h & 2 \\
Bite site & 3 \\
Fingers & 1 \\
Hand & 1 \\
Toes & 2 \\
Foot & 4 \\
Other & \\
\hline
\end{tabular}

they had no neuromuscular manifestations.

The three severe cases developed intense muscular weakness, starting between 2-3 h after the bite. An anticholinesterase (neostigmine, $\mathrm{n}=2$; edrophonium, $\mathrm{n}=1$; preceded by the i.v. administration of atropine) was used in all three patients, with the two patients who received neostigmine responding favorably. None of the patients required artificial ventilation. The first patient (20 years old), who was admitted to hospital two $\mathrm{h}$ after the bite, showed complete recovery from paralysis $10 \mathrm{~min}$ after two i.v. doses (1 mg each) of neostigmine, with no need for additional doses; this was followed by the administration of 10 ampoules of antivenom, and discharged after two days (VITAL BRAZIL \& VIEIRA, 1996). The second patient (38 years old) was admitted to UNICAMP $11 \mathrm{~h}$ after the bite, and showed progressive paralysis, despite having received five ampoules of antivenom upon admission to the first hospital (in the city of origin). At UNICAMP, the patient received a further five ampoules, with a marked improvement in muscular activity (recovery from palpebral ptosis and an ability to sit without help) after two i.v. doses (1 mg each) of neostigmine. However, there was a marked worsening of muscular force $10 \mathrm{~min}$ after the second injection of neostigmine, with the need for a continuous infusion of this drug $(12 \mu \mathrm{g} / \mathrm{kg} / \mathrm{h})$ that was suspended after six h. There was no relapse to paralysis, and the patient was discharged three days after admission (VITAL BRAZIL \& VIEIRA, 1996). The third severe case involved a 10-year-old girl who had already received three ampoules of antivenom in her home town where she had developed palpebral ptosis, muscular weakness and superficial respiration. The patient was admitted to UNICAMP six $h$ after the accident, with a worsening of myasthenia to the point that she was unable to remain in an upright position. A therapeutic test with edrophonium $(0.25 \mathrm{mg} / \mathrm{kg})$ produced no favorable response. A further 10 ampoules of antivenom were given and this was followed by the progressive and total remission of paralysis. The patient was discharged after three days. 


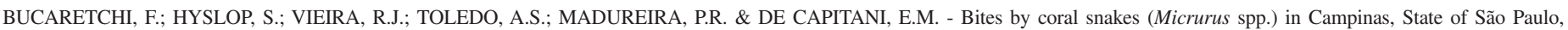
southeastern Brazil. Rev. Inst. Med. trop. S. Paulo, 48(3):141-145, 2006.

Table 2

Principal findings according to the severity of the bite in the 11 patients bitten by coral snakes

\begin{tabular}{|c|c|c|c|c|c|}
\hline Findings & $\begin{array}{c}\text { Dry-bite } \\
(\mathrm{n}=1)\end{array}$ & $\begin{array}{c}\text { Mild } \\
(\mathrm{n}=2)\end{array}$ & $\begin{array}{c}\text { Moderate } \\
\quad(\mathrm{n}=5)\end{array}$ & $\begin{array}{l}\text { Severe } \\
(\mathrm{n}=3)\end{array}$ & $\begin{array}{c}\text { Total } \\
(\mathrm{n}=11)\end{array}$ \\
\hline Snake identified & 1 & 2 & 0 & 1 & 4 \\
\hline \multicolumn{6}{|l|}{ Local } \\
\hline Paresthesia & 1 & 1 & 5 & 2 & 9 \\
\hline Pain & 0 & 1 & 4 & 3 & 8 \\
\hline Fang marks & 0 & 0 & 2 & 1 & 3 \\
\hline Slight edema & 0 & 1 & 1 & 0 & 2 \\
\hline Irradiating pain & 0 & 0 & 1 & 1 & 2 \\
\hline Erythema & 0 & 1 & 0 & 0 & 1 \\
\hline Myalgia & 0 & 0 & 0 & 1 & 1 \\
\hline \multicolumn{6}{|l|}{ Systemic } \\
\hline Palpebral ptosis & 0 & 0 & 5 & 3 & 8 \\
\hline Weakness & 0 & 0 & 1 & 3 & 4 \\
\hline Inability to stand up & 0 & 0 & 0 & 3 & 3 \\
\hline Muscle fasciculation & 0 & 0 & 0 & 2 & 2 \\
\hline Diplopia & 0 & 0 & 1 & 1 & 2 \\
\hline Superficial respiration & 0 & 0 & 0 & 2 & 2 \\
\hline Headache & 0 & 0 & 1 & 1 & 2 \\
\hline Blurred vision & 0 & 0 & 1 & 1 & 2 \\
\hline Generalized paresthesia & 0 & 0 & 1 & 1 & 2 \\
\hline Dysphagia & 0 & 0 & 2 & 0 & 2 \\
\hline Vomiting & 0 & 0 & 1 & 0 & 1 \\
\hline Salivation & 0 & 0 & 1 & 0 & 1 \\
\hline Generalized myalgia & 0 & 0 & 1 & 0 & 1 \\
\hline Muscle tremors & 0 & 0 & 0 & 1 & 1 \\
\hline Anticholinesterases & 0 & 0 & 0 & 3 & 3 \\
\hline \multicolumn{6}{|l|}{ Antivenom } \\
\hline Before arriving at UNICAMP & 0 & 0 & 0 & 2 & 2 \\
\hline At UNICAMP & 0 & 2 & 5 & 3 & 10 \\
\hline Number of ampoules per patient (median) & 0 & $5-7(6)$ & $6-12(10)$ & $10-13(10)$ & $5-13(10)$ \\
\hline Early reactions & 0 & 2 & 1 & 0 & 3 \\
\hline
\end{tabular}

Of the ten patients who received antivenom at UNICAMP (Table $2)$, mild early reactions occurred in three, with the patients showing urticaria (3/10), itching (2/10) and abdominal pain (1/10).

\section{DISCUSSION}

Bites by Micrurus spp. in Brazil are rare, with very few deaths ${ }^{6,11}$, and the cases described here confirm this situation. In the last 20 years, only 11 cases with a confirmed diagnosis or strong suspicion of having been caused by Micrurus spp. have been admitted to the university hospital at UNICAMP, and accounted for $2 \%$ of the venomous snakebites attended by this hospital (the remaining bites involved Bothrops spp., 69.8\%, and Crotalus durissus ssp., 28.2\%).

In the present series, the hands and fingers were the regions most frequently bitten, a finding that probably reflects the inappropriate or imprudent handling of these snakes, as well as their habit of holding on and chewing after the initial bite, a behavior which might prolong the time of venom inoculation ${ }^{18,19,22,27}$. As shown here, and elsewhere ${ }^{18,19,22,27}$, bites by Micrurus spp. may result in no clinical manifestations of envenoming, i.e. dry-bites, despite the high toxicity of Micrurus venoms. Occurrence of dry-bites can probably be explained by the small to medium size of these snakes, their semifossorial habits, low aggressivity, short fangs (generally $<3 \mathrm{~mm}$ ), and the limited angle of opening of the mouth $\left(\leq 30^{\circ}\right)$ making it difficult to inject venom into humans and large animals ${ }^{20}$. The true incidence of dry-bites is probably higher than that observed here since bites without envenomation may be confused with those by non-venomous false coral snakes (genera Erythrolampus, Liophis, Oxyrhopus, Pliocercus, Simophis, and others) when there is no confirmed identification of the offending species.

Pain and paresthesia were the most frequent local symptoms, occasionally accompanied by myalgia and discrete edema, as also reported elsewhere $e^{8,18-19,22,27,28,30}$. Although fang marks were detected in only three cases, the absence of such marks does not exclude the possibility that venom was inoculated and that there may be systemic manifestations ${ }^{18,19,22,24,27}$.

The use of a tourniquet was reported in only one moderate case. 


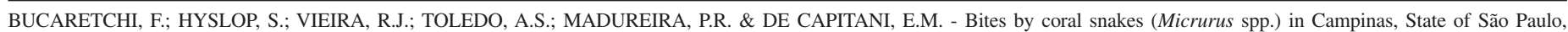
southeastern Brazil. Rev. Inst. Med. trop. S. Paulo, 48(3):141-145, 2006.

There is some discussion regarding the efficacy of this procedure in elapid bites. The quick release of a tourniquet after hospital admission can result in fast deterioration of the patient's clinical condition as a result of a rapid, massive release of venom into the general circulation ${ }^{33}$. A recent experimental study demonstrated that pressure-immobilization bandages delayed the onset of the symptoms of envenomation and increased the survival time in pigs injected with $M$. f. fulvius venom ${ }^{13}$. However, no clinical trials have been performed to test this first aid measure after Micrurus spp. snakebites. In addition, physicians and lay people may have some difficulties in applying pressureimmobilization bandages properly in a snakebite scenario ${ }^{25}$.

In four patients classified as moderate and in the three severe cases, the onset of paralysis was rapid (1-3 $\mathrm{h}$ after the bite). A similar time scale (2-4 h) has been reported for the appearance of neurological manifestations after envenoming by $M . f$. fulvius ${ }^{27}$, although these phenomena may also occur 7-18 $\mathrm{h}$ after the bite ${ }^{8,18-19}$. Regardless of the time of onset, this paralysis worsens rapidly if adequate treatment is not initiated and may result in the need for prolonged artificial ventilation. Complete recovery from severe paralysis may require up to two months ${ }^{18}$.

Part of the problem in deciding when to give antivenom in coral snake bites is the difficulty in determining whether venom was in fact injected $^{18,27}$. The immunodiagnosis of coral snake bites is not a routine procedure in Brazil, although ELISAs test for Micrurus venoms have already been described ${ }^{3}$. Another consideration is whether the mild cases (with confirmed identification of the snake) would have progressed to paralysis if the patients had not received antivenom. Based on the analysis of the moderate and severe cases reported here, and on observations made ealsewhere ${ }^{18,27}$, we think that antivenom is recommended in all cases with local manifestations (principally pain and paresthesia) concomitant with systemic signs and symptoms of acute myasthenia, regardless of the intensity, even without identification of the snake. Although no controlled clinical trials have assessed the efficacy of the elapidic antivenom used here, and there is no generally accepted clinical classification of the severity of bites, the Brazilian Ministry of Health nevertheless recommends an empirical dose of 10 ampoules of antivenom for elapid bites, regardless of the severity ${ }^{6}$.

Micrurus venoms are considered good immunogens, with good cross-reactivity that neutralizes the lethal activity of venoms from various species found in Brazil ${ }^{16,29}$. However, questions still remain about the efficacy of antivenoms for treating bites by offending species from different geographic origins ${ }^{10,21}$. Indeed, recent work has shown that the antivenom produced by the Instituto Butantan is unable to neutralize the lethality in mice of venom from $M$. altirostris (previously classified as $M$. frontalis altirostris), an important species in the southern Brazilian state of Rio Grande do $\mathrm{Sul}^{21}$. The use of a polyvalent antivenom against the main Micrurus species of North, Central and South America ${ }^{10}$ could perhaps overcome problems related to regional and intergeneric venom variations.

A clinical trial involving Naja naja philippinensis bites $^{34}$ has shown the effectiveness of anticholinesterase drugs in treating elapid envenoming with severe paralysis caused by a predominantly or exclusively postsynaptic action at the neuromuscular junction. A favorable response to neostigmine in three cases has also been observed in Brazil, two of which were attended a considerable time after being bitten $^{8,32}$. In one of our cases, which did not respond to anticholinesterase drugs, the offending species may have been $M$. corallinus, which venom acts presynaptically blocking the release of acetylcholine from nerve endings at the neuromuscular junction ${ }^{17,31}$. However, the effect of neostigmine is always temporary ${ }^{8,32,34}$, and complete reversal of postsynaptic neurotoxicity can be achieved only with antivenom.

In conclusion, the results described here indicate that bites by Brazilian Micrurus spp. should always be considered as potentially serious, although the prognosis for those bitten who developed envenoming is quite good, as long as adequate therapeutic measures are adopted. Such measures include the administration of antivenom and the provision of respiratory support, if necessary. In serious bites by $M$. frontalis or $M$. lemniscatus, whose venoms act postsynaptically, anticholinesterases may be useful as an ancillary measure if antivenom is unavailable, if there is a delay in obtaining a sufficient amount, or in those patients given the highest recommended doses of antivenom without improvement of the paralysis or with delayed recovery.

\section{RESUMO}

\section{Acidentes por serpentes corais (Micrurus spp.) em Campinas, Estado de São Paulo, sudeste do Brasil}

As serpentes corais (Micrurus spp.) são as principais representantes dos elapídeos na América do Sul. Todavia, acidentes com essas serpentes são raros. Foram revisados retrospectivamente os prontuários de 11 pacientes mordidos por corais num período de 20 anos. Destes 11 casos, quatro foram casos confirmados por identificação da serpente e sete como casos altamente suspeitos de envenenamento elapídico por apresentarem manifestações neuromusculares indicativas de miastenia aguda. Os casos foram classificados como não envenenados [n = 1, causado por M. lemniscatus, não recebeu antiveneno (AV)], leves (manifestações locais sem miastenia, $\mathrm{n}=2$, causados por $M$. frontalis e $M$. spp.), moderados (miastenia leve, $\mathrm{n}=5$ ) e graves (miastenia intensa, $\mathrm{n}=3$, um causado por $M$. frontalis). Os principais achados clínicos à admissão foram: parestesia (local, $\mathrm{n}=9$; generalizada, $n=2)$, dor local $(n=8)$, ptose palpebral $(n=8)$, fraqueza $(n=4)$, incapacidade de se manter na posição ereta $(n=3)$. Nenhum paciente desenvolveu insuficiência respiratória. O AV elapídico foi empregado em 10 casos, ocorrendo reações precoces leves em três. Em três pacientes foram administrados anticolinesterásicos, com resposta favorável em dois. Não ocorreram óbitos. A despeito da alta toxicidade dos venenos de Micrurus spp., o prognóstico do envenenamento é bom. Nos casos graves determinados por $M$. frontalis e $M$. lemniscatus, cujos venenos atuam pós-sinapticamente, o uso de anticolinesterásicos pode ser considerado caso o AV não seja disponível; caso ocorra um atraso para a sua obtenção; ou nos pacientes que receberam as mais altas doses de AV recomendadas sem melhora da paralisia ou demora na reversão desses sintomas.

\section{REFERENCES}

1. AAPCC-TESS (The American Association of Poison Control Centers. Toxic Exposure Surveillance System), 2005. Annual Reports. http://www.aapcc.org/annual.htm. Accessed: 13/7/2005 
2. ALAPÉ-GIRÓN, A.; STILES, B.; SCHMIDT, J. et al. - Characterization of multiple nicotinic acetylcholine receptor-binding proteins and phospholipases $\mathrm{A}_{2}$ from the venom of the coral snake Micrurus nigrocinctus. FEBS Lett., 380: 29-32, 1996.

3. AMUY, E.; ALAPÉ-GIRÓN, A.; LOMONTE, B.; THELESTAM, M. \& GUTIERREZ, J.H. - Development of immunoassays for determination of circulating venom antigens during envenomations by coral snakes (Micrurus species). Toxicon, 35: 1605-1616, 1997.

4. BARROS, A.C.S.; FERNANDES, D.P.; FERREIRA L.C.L. \& SANTOS, M.C. - Local effects induced by venoms from five species of genus Micrurus sp. (coral snakes). Toxicon, 32: 445-452, 1994.

5. BOLAÑOS, R. - Las serpientes venenosas de Centroamérica y el problema del ofidismo. Primera parte. Aspectos zoológicos, epidemiológicos y biomédicos. Rev. costarric. Cienc. méd., 3: 165-184, 1982.

6. BRASIL. MINISTÉRIO DA SAÚDE. FUNDAÇÃO NACIONAL DA SAÚDE - Manual de diagnóstico e tratamento de acidentes por animais peçonhentos. Brasília, Ministério da Saúde; Fundação Nacional da Saúde, 1998.

7. CECCHINI, A.L.; MARCUSSI, S.; SILVEIRA, L.B. et al. - Biological and enzymatic activities of Micrurus sp. (coral) snake venoms. Comp. Biochem. Physiol., Part A, 140: 125-134, 2005.

8. COELHO, L.K.; SILVA, E.; ESPOSITTO, C. \& ZANNIN, M. - Clinical features and treatment of Elapidae bites: report of three cases. Human exp. Toxicol., 11: 135137, 1992.

9. CUPO, P.; AZEVEDO-MARQUES, M.M.; MENEZES, J.B. \& HERING, S.E. - Reações de hipersensibilidade imediatas após uso intravenoso de soros antivenenos: valor diagnóstico dos testes de sensibilidade intradérmicos. Rev. Inst. Med. trop. S. Paulo, 33: $115-122,1991$.

10. DE ROODT, A.R.; PANIAGUA-SOLIS, J.F.; DOLAB, J.A. et al. - Effectiveness of two common antivenoms for North, Central and South American Micrurus envenomations. J. Toxicol. clin. Toxicol., 42: 171-178, 2004.

11. FAN, H.W. \& CARDOSO, J.L.C. - Clinical toxicology of snake bites in South America. In: MEIER, J. \& WHITE, J., ed. Handbook of clinical toxicology of animal venoms and poisons. Boca Raton, CRC Press, 1995. p. 667-688.

12. FRANCIS, B.R.; JORGE DA SILVA Jr., N.; SEEBART, C. et al. - Toxins isolated from the venom of the Brazilian coral snake (Micrurus frontalis frontalis) include hemorrhagic type phopholipases A, and postsynaptic neurotoxins. Toxicon, 35: 1193 1203, 1997.

13. GERMAN, B.T.; HACK, J.B.; BREWER, K. \& MEGGS, W.J. - Pressure-immobilization bandages delay toxicity in a porcine model of eastern coral snake (Micrurus fulvius fulvius) envenomation. Ann. Emerg. Med., 45: 603-608, 2005.

14. GUTIÉRREZ, J.M.; ROJAS, G.; JORGE DA SILVA Jr., N. \& NUÑEZ, J. - Experimental myonecrosis induced by the venoms of South American Micrurus (coral snakes). Toxicon, 30: 1299-1302, 1992.

15. HEARD, K.; O'MALLEY, G.F. \& DART, R.C. - Antivenom therapy in the Americas. Drugs, 58: 5-15, 1999 .

16. HIGASHI, H.; GUIDOLIN, R.; CARICATI, C. et al. - Antigenic cross-reactivity among components of Brazilian Elapidae snake venoms. Braz. J. med. biol. Res., 28: 767771, 1995.

17. JORGE DA SILVA Jr., N. \& BUCARETCHI, F. - Mecanismo de ação do veneno elapídico e aspectos clínicos dos acidentes. In: CARDOSO, J.L.C.; FRANÇA, F.O.S.; WEN, F.H.; MÁLAQUE, C.M.S. \& HADDAD Jr., V., ed. Animais peçonhentos no Brasil. Biologia, clínica e terapêutica dos acidentes. São Paulo, Sarvier \& FAPESP, 2003. p. 99-107.
18. KITCHENS, C. \& VAN MIEROP, L.H.S. - Envenomation by the eastern coral snake (Micrurus fulvius fulvius). A study of 39 victims. J. Amer. med. Ass., 258: 16151618,1987

19. McCUlLOUGH, N.C. \& GENNARO, J.F. - Coral snake bites in the United States. J. Flo. med. Ass., 49: 968-972, 1963.

20. MELGAREJO, A.R. - Serpentes peçonhentas do Brasil. In: CARDOSO, J.L.C.; FRANÇA, F.O.S.; WEN, F.H.; MÁLAQUE, C.M.S. \& HADDAD Jr., V., ed. Animais peçonhentos no Brasil. Biologia, clínica e terapêutica dos acidentes. São Paulo, Sarvier \& FAPESP, 2003. p. 33-61.

21. MORAES, F.V.; SOUZA-E-SILVA, M.C.C.; BARBARO, K.C.; LEITÃO, M.A. \& FURTADO, M.F. - Biological and immunochemical characterization of Micrurus altirostris venom and serum neutralization of its toxic activities. Toxicon, 41: 71-79, 2003.

22. NEDEL, C.A.; KLEIN, A.L.; LORA, R.C. et al. - Análise clínico-epidemiológica dos acidentes elapídicos ocorridos em Santa Catarina. In: ENCONTRO NACIONAL DE ACIDENTES COM ANIMAIS PEÇONHENTOS, 2., Porto-Alegre, Brasil, 1997. Programa. p. 44

23. NISHIOKA, S.A.; SILVEIRA, P.V.P. \& MENZES, L.B. - Coral snake bite and severe local pain. Ann. trop. Med. Parasit., 87: 429-431, 1993.

24. NORRIS, R.L. \& DART, R.C. - Apparent coral snake envenomation in a patient without visible fang marks. Amer. J. Emerg. Med., 7: 402-405, 1989.

25. NORRIS, R.L.; NGO, J.; NOLAN, K. \& HOOKER, G. - Physicians and lay people are unable to apply pressure immobilization properly in a simulated snakebite scenario. Wildn. environ. Med., 16: 16-21, 2005.

26. OTERO, R.; TOBÓN, G.S.; GÓMEZ, L.F. et al. - Accidente ofídico en Antioquia y Chocó. Aspectos clínicos y epidemiológicos (marzo de 1989 - febrero de 1990). Acta méd. colomb., 17: 239-249, 1992.

27. PARRISH, H.M. \& KHAN, M.S. - Bites by coral snakes: report of 11 representative cases. Amer. J. med. Sci., 253: 561-568, 1967.

28. PifANO C., F.; TRUjillo, M.H. \& RODRIGUEZ-ACOSTA, A. - Sobre el emponzoñamiento producido por las corales ponzoñosas del trópico americano, especialmente en Venezuela. Med. crit. venez., 1: 96-101, 1986.

29. PRIETO DA SILVA, A.R.B.; YAMAGUSHI, I.K.; MORAIS, J.F. et al. - Cross reactivity of different specific Micrurus antivenom sera with homologous and heterologous snake venoms. Toxicon, 39: 949-953, 2001.

30. SELIGMAN, R. - Acidente por Micrurus frontalis: primeiro relato de envenenamento elapídico no Rio Grande do Sul. Mem. Inst. Butantan, 55: 65-68, 1993.

31. VITAL BRAZIL, O. - Sinais e sintomas neurotóxicos do envenenamento ofídico: ação central ou periférica da peçonha das serpentes. Rev. Ass. med. bras., 36: 63-65, 1990 .

32. VITAL BRAZIL, O. \& VIEIRA, R.J. - Neostigmine in the treatment of snake accidents caused by Micrurus frontalis: report of two cases. Rev. Inst. Med. trop. S. Paulo, 38: 61-67, 1996.

33. WATT, G.; PADRE, L.; TUAZON, M.L.; THEAKSTON, R.D. \& LAUGHLIN, L.W. Tourniquet application after cobra bite: delay in the onset of neurotoxicity and the dangers of sudden release. J. trop. Med. Hyg., 38: 618-622, 1988.

34. WATT, G.; THEAKSTON, R.D.G.; HAYES, C.G. et al. - Positive response to edrophonium in patients with neurotoxic envenoming by cobras (Naja naja philippinensis). A placebo-controlled study. New Engl. J. Med., 315: 1444-1448, 1986.

Received: 26 October 2005

Accepted: 21 February 2006 